\title{
Should the Playing Field Be Leveled? Funding Inequities Among Division I Athletic Programs
}

\author{
John M. Dunn \\ Western Michigan University
}

\begin{abstract}
Significant funding inequity exists within Division I athletic programs. The widening gap between heavily resourced university athletic programs and those less resourced is explored, explained, and then analyzed. Considerations are offered to help frame continued discussion and include regulating the number of ancillary personnel, creating a financial support bandwidth for conference membership, distributing media income, and scaling success differently.
\end{abstract}

The intersection of money and sports continues to be at the heart of the debates whenever collegiate athletics is the topic. It's not a new topic, but it is timely. With funding inequities already pronounced in some conferences, we are about to embark on a new era of student-athlete subsidies that is certain to dramatically widen the gap between the "have" and "have-not" athletic programs. I have had a front-row seat to follow collegiate sports programs as a member of the academy for more than 40 years. It is a career path that has taken me from the University of Connecticut, to Oregon State University, the University of Utah, Southern Illinois University and now, Western Michigan University.

Resource differences, of course, exist in every area of academe. Many outside our campuses will ask why so much money and attention is focused on athletics, an activity that is not part of our core mission of higher education. The answer is a simple one. There is no other collegiate activity-academic or extracurricular-that rivals athletics when it comes to engaging students and alumni, motivating donors, attracting new students, and engendering name recognition. Some will point out that when a poetry reading attracts a crowd of 25,000 attendees, we'll likely pump similar resources into our poetry program. I can say that as the leader of a university with an incredibly strong poetry program. The point is that the benefits of athletic success are sometimes overstated, but they are very real.

Money does not buy success, but it certainly makes that success easier to come by. Money buys superior facilities_-stadiums, practice arenas and weight rooms. It buys good coaches, savvy advisors, and academic tutors. What money does not buy is an environment that is so secure in its strength that it prevents rule violations. I will argue that the opposite is actually the case. Counter to what one would imagine, institutions with the best resources often are prone to shortcuts. Perhaps

Dunn is the president of Western Michigan University, Kalamazoo, MI. 
they are too accustomed to the idea that money is the answer to any problem. I think the evidence shows that the schools in those conferences with a broad resource bandwidth may be those most likely to experience major NCAA violations.

\section{The Existing Problem}

In Division 1 programs, there is very little dispute that some universities spend a great deal more on athletics than do others. This point has been documented and commented on by several sources, including the NCAA (USA Today, 2012). We have conferences in which the range of financial support for members-what I will call bandwidth in this paper-exceeds $\$ 100$ million (USA Today, 2012). That means that within a single conference, athletics programs with a resource gap of $\$ 100$ million find themselves competing with each other.

The top-tier spenders, programs such as the University of Texas, have operating revenues and can spend approximately six times more than programs such as my home institution, Western Michigan University. The total amount of money spent on athletics by 9 of the 11 schools in the Sun Belt Conference is less than the amount spent by the University of Texas (Wieberg, Upton, \& Berkowitz, 2012). The range of operating revenues for Division 1 athletic programs runs the gamut from a low of $\$ 3.5$ million to a high of $\$ 150$ million (USA Today, 2012). Yet, these teams are expected to compete successfully on the gridiron and other venues for athletic competition. Is this right or simply a matter of fact that some have more than others and so be it? Should the NCAA try to regulate expenditures, similar to the manner in which the number of scholarships are governed or not? Let me be clear, I do not have the answer to these and other serious and complex questions.

One thing not in dispute, however, is that the gap between the more heavily resourced university athletic programs and those less resourced is widening, and it does not appear likely that anything in the near future will stop the escalation. In Table 1, I provide a list of the 10 schools with the highest level of resources for their athletic programs.

\section{Table 1 Resources of the Top 10 Funded Athletic Departments}

\begin{tabular}{llc}
\hline Rank & Program & Funding Amount \\
\hline 1. & University of Texas-Austin & $\$ 150$ \\
2. & The Ohio State University & $\$ 132$ \\
3. & University of Alabama & $\$ 124.5$ \\
4. & University of Florida & $\$ 123.5$ \\
5. & University of Michigan & $\$ 123$ \\
6. & Pennsylvania State University & $\$ 116$ \\
7. & Louisiana State University & $\$ 107$ \\
8. & University of Tennessee & $\$ 104$ \\
9. & University of Oklahoma & $\$ 104$ \\
10. & Auburn University & $\$ 104$ \\
\hline
\end{tabular}

Note. Funding amount in millions. Data adapted from Upton and Berkowitz (2012). 


\section{Why the Differences}

If the number of scholarships allowed per institution is governed by the NCAA, why are the differences among the institutions so large? A simple explanation, of course, has to do with the number of teams sponsored as well as the unit cost of tuition. Some schools offer more competitive sports for men and women than others and there are wide differences in the cost of tuition per institution. However, these factors do not account for the major differences among institutions. Other factors, such as coaches' salaries, number of personnel other than coaches, training facilities and medical staff, marketing expenses, facility investments and upkeep, travel for recruiting, amenities associated with locker rooms and study halls, and the recent option to provide tuition for Summer Session create even wider variations in the overall budgets.

The bottom line is that some institutions choose to expend more to support their athletic programs. Some argue that the large amount spent brings notoriety and alumni pride to the institution. And, of course, 22 of the 227 public schools in NCAA Division I can argue that they make money via their athletic programs (Upton \& Berkowitz, 2012). Conversely, this means that 205 of the programs have to look for other sources, including internal funds to support their programs. In these cases, justification for the expenditures relate to institutional pride and the value of sport as part of the fabric of society.

\section{Conference Analyses}

One might argue early on that whining about an institution's national athletic standing is inappropriate. The critic might further argue to reset aspirations, find a conference alignment that fits the institution's financial commitment and thereby compete against like institutions with similar athletic resources. This is a reasonable position and works well for athletic conferences that do have a narrow resource bandwidth. I have always thought that the Mid-American Conference (the MAC) is quite special because the outstanding institutions that comprise the league all spend about the same in support of their athletic programs. What I am calling the spending bandwidth, in the MAC is just $\$ 9$ million (USA Today, 2012). Despite the MAC's relatively modest and narrow bandwidth, its teams compete strongly in the national arena. Recent MAC achievements include:

- Four conference football teams in top 25 during the 2012 season,

- One football team in a BCS bowl game,

- A top five finish in men's golf,

- A College World Series appearance,

- A national championship in men's soccer,

- A sweet-16 appearance in men's basketball, and

- A WNIT championship in women's basketball.

Remember that information for a bit, I will return to it later in this paper.

The MAC has long been known as a hot bed for the development of outstanding football coaches who go on to "larger, better resourced" universities. Examples 
include Urban Myer (Ohio State), Brian Kelly (Notre Dame), and Brady Hoke (Michigan), just to name a few. Their success may relate in part to the fact that they participate in a league of equals with respect to resources. Success required recruiting good athletes, finding talented assistants and using the resources available to compete and, of course, win. No one did it by outspending conference opponents. The comparisons within conferences are not perfect and they are influenced by the number of sports a school sponsors as well as the type of sports. For example, in the Mid-American Conference three schools have Division I Hockey Programs, and the number of sponsored teams among conference participants also varies. However, each school does sponsor the major sports of football, basketball (women's and men's), and women's volleyball.

So, assuming that a conference adheres to a narrow bandwidth for athletic expenditures and does reset aspirations to focus on the conference crown as the ultimate measure of a successful season, what is the reward? Pursuit of the conference championship worked well in the early years when the invitation to the Men's NCAA Basketball Tournament was limited only to the conference champion. However, times changed, and some questioned the fairness or wisdom of such a restrictive policy that limited selection for national play only to the conference champion.

Thus far, I have limited my observations to an analysis of only one conference, the Mid-American Conference. What about other leagues and the bandwidth of resources in those alignments. By highlighting the operating revenues of three other conferences - the Big Ten, Big XII and Mountain West-and adding in the aforementioned Sun Belt Conference, this telling picture emerges.

As seen in Figure 1, the expenditure ratio of low to high with the conferences ranges from a low of 1.42 for the MAC to a high of 3.09 for the Big XII (USA Today, 2012). This analysis suggests that even within a conference the differentials for some of the conferences are large and some might argue larger than desired.

\section{Conference Bandwidth Comparison}

\section{$\$ 9 M$ (๑)
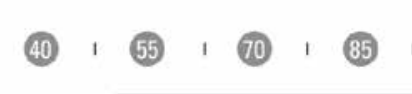 \\ 기 : (1): \$150M}

\section{Big 12}

\section{Big 10}

\section{Sun Belt}

\section{Mountain West}

\section{MAC}

Figure 1 - Note. Derived from "Sports college athletics finances: Details of revenue and expenses at NCAA D-1 public schools", May 14, 2012, USA Today. 


\section{Beyond Money: Less May Be Better}

One of the major concerns expressed by sport fans and detractors is the high cost associated with university athletic departments. Many pundits identify the huge salaries paid to coaches, primarily football and men's basketball coaches, and question whether the universities have lost their focus. Earlier, Peter Likins, former president of the University of Arizona, in chairing a committee for the NCAA, argued that the current spending level will create stresses that will ultimately lead to the demise of college sports. Others, such as William Powers, president of the University of Texas, while not advocating for a split between the "haves" and "have-nots," believes this may be the ultimate outcome, given the current level of funding discrepancies.

Is there a danger of providing too much funding and, therefore, too much emphasis on athletics at the collegiate level? In a late 2011 article in the Wall Street Journal, 17 institutions of higher education were cited for having "clean" programs (Everson \& Karp, 2011). Clean was defined as a Football Bowl Subdivision program whose teams have never been found guilty of a major NCAA violation in any sport since 1953 when the NCAA began tracking rule violations. Since the Wall Street Journal report on those of us called "the last innocents," the number has been reduced to 16, given the recent sanctions imposed on Penn State University. A summary of the "clean" schools suggests:

- Five are from the MAC (Bandwidth of $\$ 9 \mathrm{M}$ )

- Three are from the Sun Belt (Bandwidth of \$16M)

- Two are from the Mountain West (Bandwidth of \$37 M)

- The remaining six were spread across other conferences, including the lowest resourced institution in the Big Ten, Northwestern (Rittenberg, 2011)

While it may be difficult to support an argument that too much funding creates problems, it is not a stretch to argue that within conference differences in expenditures may make it very difficult for low resourced programs to compete. Given the pressure on winning, and job security, it is not difficult to imagine the vexing temptation to cut a corner by ignoring one of the vast number of NCAA rules and regulations.

\section{Options: Are There Viable Alternatives}

One could reasonably argue that the funding inequities among schools, even like schools within conferences, are simply a matter of institutional priorities. If so, then the status quo is the solution. Some schools will continue to spend whatever is necessary to have winning teams. Some low resourced schools, in an effort to keep up, will search for new revenue streams, including greater access to institutional resources. This latter path is dangerous, given the increasing concern about student fees, rising tuitions, and decreasing state support. Other low-resourced schools might choose to simply take it on the chin, continue to compete, but acknowledge that winning is an elusive goal. And, of course, some may opt to move down a division where the costs are not as great or align with a conference that is committed to a narrow bandwidth regarding expenditures. 


\section{Regulate the Number of Ancillary Personnel}

Many acknowledge that there are an increasing number of ancillary personnel associated with athletic programs. These are individuals not directly involved in the coaching of a sport or providing care for the athlete, such as physicians or athletic training personnel. In many big-time sports programs, there is a new cadre of athletic department personnel. These include individuals with titles, such as game video analysts, directors of academic support services, nutritionists, sport psychologists, compliance personnel, conditioning specialists, and so on.

For illustrative purposes, Ohio State and the University of Texas each employ 23 individuals to offer their student athletes academic support. In the Mountain West and Mid-American conferences, the comparable number is approximately six. The number of teams and athletes accounts some of the differences, but the variance is still far greater than one would think. I do not believe, either, that athletes at Ohio State or Texas are less academically qualified.

If the NCAA were to regulate the number of ancillary personnel, similar to the approach related to the number of coaches, athletic expenditures would be reduced and the field would be more level with respect to recruiting advantages. The big winner might be the athletes who are more fully integrated into the university, rather than isolated in study halls and facilities dedicated only to them.

\section{Create a Bandwidth for Conference Membership}

As noted previously, there was an earlier time when greater attention was focused on conference championships and teams competing with equals. Less attention was on identifying a national champion. In recent years, the focus on the national championship has increased as a result of the cry from fans and media for clarifying who is "really" No. 1 in the nation. I doubt seriously that anything will dissuade increasing pressure for clarification to define the best of the best.

However, I do think the NCAA could play a role in helping to better organize conferences with respect to bandwidths on expenditures and geographic boundaries. What I am proposing is an understanding that participation in a selected conference would require that like-resourced schools would be members of the league. In addition, the geographic locations would be regulated to further reduce travel costs. A side benefit of the latter would be a reduction in the number of classes missed by the athletes, as less travel time is related to more seat time in the classroom.

\section{Distribute Media Income}

I recognize that this is a nonstarter, but I would be remiss if I did not point out the significant inequities in media rights between the haves and the have-nots. The product — the game and competition — extend beyond a few select universities and conferences. Without the "rest" of the schools to round out the schedule, the offerings of any one conference would be limited. The heavily resourced universities enjoy playing the less-resourced universities for early season games as warm ups to conference games. Standard practice calls for these games to be played at the heavily resourced school with a minimal guarantee provided to the less-resourced school. While the guarantee helps, the amount is small in comparison with the gate receipts for the game as well as the associated television rights. Greater revenue 
sharing would help to offset some of the huge discrepancies in resources. No one, including this author, believes that this is a likely outcome. However, there is some encouragement on this point, given that the leadership of the Bowl Championship Series has given some signals of willingness to do more with revenue sharing than has been evident in the past.

\section{Scale Success Differently}

Given that high-resource and low-resourced schools are going to continue to compete, perhaps it might be interesting to establish a national ranking that is adjusted based on the amount of resources a team has to work with. For example, in the recently completed 2012-13 bowl season, the clear No. 1 national team, based on resources, would be Northern Illinois University. The total budget for the Huskies' athletics program is approximately 25 million (USA Today, 2012). They competed successfully in the Mid-American Conference and ended up being ranked nationally as the 15th best football team in the nation. As such, the Huskies were invited to the Orange Bowl and, despite being beaten by Florida State University ( $\$ 78.5$ million in resources) (USA Today, 2012), performed admirably. The amount of funds expended by NIU is clearly modest, yet they maximized their return on investment such that it would be hard to argue that they would be denied No. 1 ranking as the most financially efficient team in the country. In years past, similar arguments could have been made for other schools, including Boise State University with its exciting upset win over Oklahoma in the 2008 Tostitos Fiesta Bowl. While few may pay attention to a ranking system of this nature, it would help to remind others that financial resources may not always equate to success. Surprises do occur and efficiency in expenditures could lead to a significant return on investment, as well as recognition for those schools that manage to economize and compete well.

\section{Summary}

There is no dispute that a significant inequity in funding for Division I athletic programs exists. The differences are apparent on a national basis as well as within conferences. The latter is particularly alarming, given that the original concept of conferences was to have teams of like mission, academic profile, geographic location, and financial resources compete to determine a champion.

It is difficult to imagine how one school spending three times less than another school within the same conference can compete successfully. The remedy for this might include establishing bandwidth in expenditures as a mechanism for controlling conference affiliation. Another suggestion is to rein in expenditures, particularly as related to personnel that are ancillary to the mission at hand, which is fielding a team that is well coached with adequate personnel to attend to medical and safety needs. Such measures would clearly reduce overall expenditures and serve to help reassure the public that the race to spend "more on athletics" is not without limit.

Some might argue that the solution is really to create divisions within athletics where the alignment is based on financial resources and commitments. The question here, of course, is how to best bracket the divisions and, given that only 22 of the 227 Division I schools are profitable (Wieberg et al., 2012), would it not be better to curtail spending rather than allow the expenditure escalation to 
continue? Any limits to program spending are unlikely to harm the high level of competition that is the hallmark of NCAA Division I athletics. I remind readers of the accomplishments of MAC teams I shared earlier in this paper and the modest resources with which that conference works. Would any of these changes to the structure of Division I athletics positively or negatively impact the well being of our student athletes and their ability to perform successfully in both the academic and athletic arenas? Forty years of observing college athletics leads me to believe the results could only be positive.

\section{References}

Everson, D., \& Karp, H. (2011, June 22). The NCAA's last innocents; as scandals abound, we ask: Are there any schools left that haven't been in big trouble? USA Today. Retrieved from http://online.wsj.com/article/SB1000142405270230393670457640005212286 3390.html

Rittenberg, A. (2011, July 12). Pay for play: Northwestern. ESPN.Com. Retrieved from http:// espn.go.com/blog/ncfnation/post/_/id/43761/pay-for-play-northwestern

Upton, J., \& Berkowitz, S. (2012, May 15). Budget disparity growing among NCAA Division I schools. USA Today. Retrieved from http://usatoday30.usatoday.com/sports/college/ story/2012-05-15/budget-disparity-increase-college-athletics/54960698/1

USA Today. (2012, May 14). [Graph illustration Sports college athletics finances: Details of revenue and expenses at NCAA D-1 public schools, 2006-2001]. Retrieved from http://usatoday30.usatoday.com/sports/college/story/2012-05-14/ncaa-college-athleticsfinances-database/54955804/1

Wieberg, S., Upton, J., \& Berkowitz, S. (2012, May 15). Texas athletics overwhelm rivals in revenue and spending. USA Today. Retrieved from http://usatoday30.usatoday.com/ sports/college/story/2012-05-15/texas-athletics-spending-revenue/54960210/1 